\title{
Bob Dylan and Religion
}

$\mathrm{T}$ his article is a discussion of the relations of one particular rock artist, Bob Dylan, to religion. Bob Dylan is one of the most influential artists of the rock era. After a career spanning almost fifty years and over forty albums, he still continuously tours around the world. He has been the subject of many biographies and studies. Religion can be seen as a recurring topic in Dylan's work-particularly during a period at the end of the 1970s and beginning of the 1980 s, often referred to as his 'Christian era'-and also in the discourses around him. This article explores how the topic of religion appears in discourses around Bob Dylan. ${ }^{1}$

This article is located within the field of research on religion and popular culture, which has emerged as a small subfield within religious studies during the last decade or so (e.g. Forbes \& Mahan 2000; Mazur \& McCarthy 2001). The perspective in the field is here a sociological one, where the connection between religion and popular culture is seen as an example of how religion relates to contemporary society. Popular culture is an important part of contemporary society and one to which religion also relates; popular culture is an area where religion appears today.

Here I want to look at one particular aspect of the connection between religion and popular culture: the construction of certain artists or stars as religious figures, and more specifically I will talk about one artist, Bob Dylan, as a case. I want to emphasize that I am not trying to discover whether Dylan is religious or not; nor am I trying to find out which religion he possibly adheres to. Rather, I am looking at how rock artists and in this case Bob Dylan are 'constructed' as religious figures; or, putting it differently, I am looking at how religion appears in various texts and discourses around Bob Dylan. ${ }^{2}$

1 I want to thank Maria Punnonen and Pål Ketil Botvar for helpful comments and suggestions.

2 There are many other artists that could be interesting to discuss from the same perspective. In previous studies, I have analyzed discourses on religion in relation to artists such as Sinead O’Connor (Häger 2005), Madonna (Häger 1996), Bruce Springsteen (Häger 2006) and Thomas Di Leva (Häger 2004). 
The article presents an example of how people today encounter religion outside its institutional context and in popular culture. I believe that the example shows that religion is relevant in a sphere such as pop culture, but not necessarily in ways that are very familiar to those well acquainted with institutional religion. The article thus shows an example of how religion has become detraditionalized (cf. Woodhead \& Heelas 2000).

In the following passage I will briefly discuss two theoretical concepts that are used as starting points for the article. The main part of the article then continues with a presentation of some examples of how religion appears in discourses around Bob Dylan.

\section{Theoretical concepts}

The first concept is borrowed from the Finnish cultural historian Janne Mäkelä (2002). It is the concept of 'starnet'. The point of the concept is to serve as a reminder that the meaning of a (movie or rock) star is not created by or fixed to one single individual but rather created in a 'web' (or 'net') of texts and practices. This starnet which creates the meaning of a star has four aspects, according to Mäkelä (2002). These are: the individual artist, his or her biography and works; the industry that produces, distributes and markets the works; the media; and the audience or the fans.

The concept of starnet here serves two purposes. Firstly, it is a tool for organizing the presentation of the material on and the discussion around a particular star. Secondly, and more importantly, it reminds us that there is more to a 'star' than what is said and done by a single person; or, in other words, if I want to study the meaning of Bob Dylan, it does not suffice to look at, for example, his song lyrics or other things he himself has uttered. Furthermore, if I, for example, am interested in the biography of Dylan, I will not know anything without the information I get through media; nor do I have any access to his works without the distribution by the music industry. The concept of the starnet shows that all these aspects are interrelated.

The second concept I want to present is that of 'sacralization'. I am not here talking about stars in general or Bob Dylan as a star in general, but about how these stars-exemplified by Dylan - are constructed as religious figures, how they in various discourses are related to religious traditions. This I understand as a form of sacralization. With Linda Woodhead and Paul Heelas (2000), I see sacralization as a parallel countertrend to secularization, here particularly in the sense of an 'increase' of the presence of religion in public space, or 
rather as the increase of observation or perception of religion in public space. The concept of sacralization remains in the background in the main part of the article and is discussed more explicitly in the conclusion.

Sacralization in relation to discussing pop culture stars as religious figures could be understood at various levels. Most basically, it could refer to how artists are held in such high esteem that they could be said to be 'worshipped' as 'idols'. Stars could be seen as religious figures in a functional sense. Here, however, I will focus on how artists are connected to religious traditions in a substantive sense. This can also be seen at different levels. A first and most basic level would be simply to state a connection between an artist and a religious tradition, as for example in saying that Bob Dylan attended Bible school. A second and more interesting level is then the discourses on what such connections may mean; for example the discussion on whether Dylan still is a Christian, how Christianity might influence his work, and so on. This is the level at which most of the discourses referred to in this article are to be placed. Furthermore, it is still possible to discuss what kind of religious figure Dylan may be constructed as: a messiah, a prophet, and so on. ${ }^{3}$

In the remainder of the article, I will use the categorization of the starnet to study the construction of Bob Dylan as a religious figure. Dylan is a prolific artist with a long career, and the literature on the artist is abundant. The discussion on Dylan and religion in this article is therefore bound to be limited to a small number of examples. To attempt some form of delimitation, the main focus will be on Dylan's relation to Christianity, but it is important to remember that the discourses on Dylan also relate him to many other traditions.

\section{The artist}

Bob Dylan was born as Robert Zimmerman in Duluth, Minnesota in 1941. ${ }^{4}$ His family was Jewish and he was bar mitzvahed at the age of thirteen. However, Dylan's most publicized personal involvement with organized religion must be his conversion to Christianity in 1979. He was baptized in

This last aspect is, for the sake of brevity, left out of this article. The construction of Dylan as 'prophet' is perhaps the most common within this category, and can be found in, for example, Marshall (2002) and Gilmour (2004), who both compare Dylan to the biblical prophets Jeremiah and Jonah. 
a (Pentecostal) Vineyard church in California and attended Bible school for some months in the spring of 1979. At the beginning of the 1980s, he was reported as having returned to Judaism, and he has later been involved in Orthodox Jewish charity work and has been reported to attend synagogue occasionally ('Singer/Songwriter...').

Trying to decide what may be the 'religious aspects' of Dylan's biography is of course very much a matter of interpretation. The same goes at least to the same extent for his artistic output. I will, however, here provide some examples of what may be seen as the most explicit references to narrowly defined religious traditions in Dylan's work, and come back to the issue of interpretation in the passages on discourses on Dylan and religion in the media and among fans.

The most explicitly religious material in Dylan's work is doubtlessly the two albums following his Christian conversion, Slow Train Coming and Saved. The subsequent album, Shot of Love, is often counted as the third part of Dylan's 'religious trilogy', but contains a more mixed material than the two previous albums. The songs include 'In the Garden', which presents some of the events in the life of Jesus as depicted in the gospels, and 'Saving Grace' talking of the one road that leads to Calvary. ${ }^{5}$ On his first-self-titled-album of 1962, containing renditions of traditional songs, Dylan sings the spiritual 'Gospel Plow. He has covered gospel songs also later in his career, notably on the tours conducted in the years 1999 and 2000, which regularly featured songs such as 'Rock of Ages' and 'Pass Me Not Oh Gentle Saviour' (Dylan - The Yearly Chronologies). He has his own radio show, where each program deals with a certain theme and here he has, among other themes (such as 'weather', 'birds', and 'smoking', etc.), talked about the Bible (Theme Time Radio Hour). References to the Bible in Dylan's lyrics will be discussed below.

Bob Dylan is not known for being very talkative on stage, but during the period when he performed only gospel songs, he often gave lengthy speeches between songs. These speeches often amounted to sermons, particularly centring on Dylan's belief in a coming apocalypse. He even once condemned rock music from the stage (1979 First Gospel Tour; Heylin 1990). On tour in 1986, Dylan regularly introduced the above mentioned song 'In the Garden' as being a song about his hero (e.g. Marshall 2002: 86). In 1991, on the other hand, he often introduced the opening track from his first gospel album, 'Gotta Serve Somebody' as an 'anti-religion song' (Marshall 2002: 109). 
Dylan is not referring exclusively to Christianity or to the Judeo-Christian tradition. On the Desire album, for example, there are several references to Egyptian mythology, as in the song 'Isis', and rather more obscurely in 'Oh Sister'. There are also pictures of tarot cards on the record sleeve of that album. During the same tours in 1999 and 2000, where he performed the old gospel songs mentioned above and others like it, he also covered the Grateful Dead song 'Friend of the Devil', with the lyrics 'a friend of the devil is a friend of mine' (Dylan - The Yearly Chronologies). ${ }^{6}$

\section{Industry}

A rock artist cannot exist without some form of music industry, producing, marketing and distributing the artist's work, and to a great extent the artist him/herself. In Dylan's case, the record company obviously played a role in making and distributing Dylan's gospel records. Some songs from this period have also been included on subsequent collections. During 1979 and the spring of 1980, Dylan only played his gospel material in concert, discarding his old songs. He started including old material again in the autumn of 1980 . There are no official live recordings released from the concerts of Dylan's 'Christian' period. Dylan received a Grammy for the song 'Gotta Serve Somebody', which of course is a sign of recognition from the music industry.

One particular conflict with the music industry during Dylan's gospel years concerned the cover of the album Saved. The cover shows a large hand stretching down towards a number of smaller hands reaching up (Dylan 1980). Clinton Heylin (2003: 523) interprets the cover as depicting 'Christ's extended forefinger picking out a believer's upraised hand from a sea of damned souls'. He quotes the cover artist, Tony Wright, as saying that the record company hated the sleeve and did not want to promote another gospel record. The album was finally shipped to the radio stations in a white sleeve (Heylin 2003: 524, 426) and the cover was changed in 1985 (Saved 1980).

Dylan's songs have been performed and recorded by many other artists, and this is also true of the gospel songs. A notable example is the project called 'Gotta Serve Somebody', where a number of prominent African American gospel artists recorded gospel songs by Dylan, released on a CD and DVD (Gotta 
Serve Somebody 2003). Dylan's music, from his gospel period as well as other songs, have been used in churches for example in a number of 'Dylan masses' celebrated in churches both in Sweden and Norway (Kultursamverkan; Løvli 2002; Saving Grace 2007). This is also part of the distribution of Dylan's songs and a part that of course very clearly relates him to religion and even organized religion.

However, taking industry in a more strict sense as meaning the record industry and Dylan's record company (Sony BMG Music), I believe this is the aspect of starnet where the connection to religion is the least evident. Indications of this are the above mentioned reluctance to issue a live recording from the gospel period, as well as the fact that Dylan's gospel period seems to be a part of his career that includes many unreleased compositions (Björner; Heylin 2003: 731-47). The record industry is less willing to construct a star as religious than are artists themselves, or the media or the audience.

\section{Media}

This is perhaps the most important aspect of the starnet: the arena where the meaning of a star is first and foremost created. The media discourses on Dylan are, given that he has a long career as a very prominent artist, of course very extensive and also quite diverse, including printed press and various electronic media, as well as a large number of books, from biographies to academic treatises.

Religion comes up as a topic in many different media texts about Dylan. He has talked about religion in interviews during his gospel period (e.g. Cott 2006: 271-84). He has touched on the subject in various ways in later interviews as well. In an interview for the CBS program '60 minutes' in 2004, he explained that he continues touring because he 'made a bargain with the chief commander of this world and the world we can't see' (Dylan on '60 minutes'). In 2007, in an interview for Rolling Stone Magazine, he answered a question regarding whether he is religious:

Where can you look in the world and see that religion has been a force for positive good? Where can you look at humanity and say, 'Humanity has been uplifted by a connection to godly power?'. . Religion is something that is mostly outward appearance. Faith is a different thing. (Wenner 2007: 50.) 
and specifies when asked that he has faith in 'Nature. Just elemental nature.' It is clear that Dylan in this quote distances himself from the label 'religion'.

Religious aspects also come up in reviews of Dylan's records. The New York Times headlined its review of Dylan's 2006 album, Modern Times, 'The Pilgrim's progress of Bob Dylan' (Pareles 2006). The review says that Dylan is 'haunted by God', that his songs show 'a longing for salvation' or can 'be taken as avowals of faith. The magazine Christianity Today says in the review of the same album:

[Dylan's latest records have] summarized everything that he's ever said before: The world is going to pot, humanity is nothing but a bunch of cads and villains, women are nothing but trouble, death lies in wait around every corner, and only God can save us now.

...

For the faithful, though, there's still one light shining in the night sky, and it's enough to make the journey bearable. Dylan reminds us of this beacon in 'Thunder on the Mountain,' and it's enough to carry us through the rest of the album: 'Some sweet day,' he vows, 'I'll stand beside my king.' (Hurst 2006.)

These reviews are examples of how religious interpretations have been applied to Dylan's later work. The English writer Chris Gregory (2007) criticizes these interpretations of Dylan. Instead he suggests that the phrase 'the gardener is gone', from the final song on Modern Times, 'Ain't Talking', states that we have been abandoned by God.

There is an abundance of critical literature on Dylan, and much of this material touches upon religion; some of the critical literature deals exclusively with this topic. The literature on Dylan and religion includes Christian books focusing on Dylan's Christianity in general (Williams 1985; Marshall 2002; Webb 2006) or particularly on his use of the Bible (Cartwright 1985; Gilmour 2004). There are publications viewing Dylan from the perspective of other religious traditions such as astrology (Ledbury) and of course Judaism. Examples of the latter include an analysis of the kabbalistic references in the album Infidels (Moaz 2005); as well as a report from Dylan's 1974 American tour, titled Bob Dylan Approximately: A portrait of the Jewish poet in search of God: A Midrash (Pickering 1975). There is academic theological work on Dylan (e.g. Friberg 1999). There are critical studies pursued outside a religious context focusing on certain religious or existential aspects of Dylan (Williams 1980; Ricks 2004). Major general critical works (Gray 2000; 
Williams 2004) as well as many biographies (e.g. Shelton 1986; Sounes 2001; Heylin 2003) include analyses of Dylan's religious output. There are also some DVD-documentaries with material, mostly interviews with musicians and record producers, regarding Dylan's gospel period (Bob Dylan 1978-1989; Bob Dylan 1975-1981).

I here want to give some examples of how Dylan's religion is treated by some writers and analysts. The first example is a general look at Dylan's career from a Christian perspective; the second is a book on Dylan and the Bible; and the third example is an analysis of Dylan from an esoteric perspective.

Restless Pilgrim: The spiritual journey of Bob Dylan (Marshall 2002) is an example of a book looking at Dylan's career from a Christian perspective. The focus of the book is on the period when Dylan was explicitly Christian, 1979-81, and his subsequent career. The book basically argues that Dylan has continued to be a Christian since 1981, and if he sometimes engages in Jewish activitiesattends synagogue, for example - it is because Dylan believes, as does Marshall, that it is possible to be both a Jew and a Christian at the same time.

Scott Marshall comments on the fact that Dylan stopped writing new gospel songs after 1981:

Jesus was, and is, the answer to the question [Dylan] and his generation had been asking for so long. He saw no need to repeat himself by continuing to write gospel songs or continuing to preach from the stage: truth is truth, and it stands for ever. (Marshall 2002: 57.)

He calls the album Oh Mercy from 1989 'practically a companion piece' to Slow Train Coming (Marshall 2002: 98). In 1991, Dylan often called 'Gotta Serve Somebody' an 'anti-religion song' when he introduced it in concert. Marshall (2002: 109) argues, to my mind quite convincingly, that this is a statement based on an Evangelical view that Christianity is not a religion (cf. statements to the same effect in a radio interview with Dylan made in 1979; Cott 2006: 272). Marshall (2002: 109) draws the conclusion: 'In the end, there seems to be little doubt that Dylan's 1991 stage raps simply affirmed the reality of his experience with Jesus back in 1979.'

These are some examples of how Marshall (2002) attempts to argue that Dylan still is a Christian and that this influences his work. The arguments are not always convincing and are based on a rather narrow view of Dylan. There is, for example, a reference to St Peter in one of the songs on Oh Mercy, but this hardly makes it comparable to the very explicit gospel material on Slow Train Coming. 
Michael Gilmour (2004) analyses how Dylan has been influenced by the Bible in his lyrics. Gilmour cites some obvious and often commented upon examples, such as the references to Judas Iscariot in 'Masters of War' and 'With God on Our Side' as well as the reference to Matthew 19:30, 'But many who are first will be last, and many who are last will be first', in 'The Times They Are A-changin'. Gilmour (2004) does not pay much attention to the gospel records, perhaps in an implicit support of the thesis that Dylan always has been religious.

Gilmour also produces some more original analyses, for example when he sees Dylan's 2001 album Love and Theft as a retelling of the Exodus story. Some of the observations regarding this album are more plausible, as when Gilmour (2004: 92) compares the mention, in the song 'Mississippi', of a river crossing, with the Israelites' crossing the river Jordan. Other comparisons are less convincing to me:

[J] ust as the Israelites were trapped against the shores of the Red Sea by Pharaoh's army (Exodus 14:5-31), so too the narrator [of the song 'Mississippi'] is 'all boxed in' with no escape route available (Gilmour 2004: 92).

Associating a very general phrase such as being 'boxed in' to the biblical tale of the children of Israel escaping from Pharaoh to my mind takes a lot ofand perhaps too much-creative imagination, or rather a very strong will to claim that Dylan is even more influenced by the Bible than is obvious in a superficial reading of his work.

The Italian Dylan scholar Nicola Menicacci has written extensively in Italian on Dylan's connections to esoteric tradition. On his website, Menicacci summarizes some of his analysis in a number of video statements in English (Nicola Menicacci videos). He discusses the connections of Dylan's work to I Ching, tarot and the story of Mary Magdalene's journey to France. In one video, he states that there is a different message behind Dylan's so called Christian albums. Menicacci observes that on the back cover of the albums Slow Train Coming, Saved and Shot of Love there can be found (among other things) a cross, a light ${ }^{7}$ and a rose. Taken in reverse, these three words give the initials RLC, which according to Menicacci is a reference to the French village Rennes-Le-Chateau, said to be the place where the documents on the Priory of Sion were discovered (Rennes-Le-Chateau: The Mystery; Baigent 
et al. 2005). As with any interpretation, Menicacci's analysis of the esoteric content in Dylan's records is open to criticism, but I find his comments to be an interesting example of how the work of an artist such as Bob Dylan can be and is interpreted from many perspectives, including many different religious traditions. Both Marshall (2002) and Menicacci also serve as examples of how interpreters who like a particular artist, in this case Bob Dylan, attempt to incorporate Dylan into their own sphere, claiming Dylan to be one of their own.

\section{Fans}

The fourth aspect of the starnet is the audience or the fans of the star in question. Dylan has a large fan base, and many fans are very devoted when it comes to following Dylan's career in various ways. It is important to note that contemporary fandom points to the fact that the distinction between media and audience and even between industry and audience is difficult to make. Fans are critics (and critics are fans), and fans form part of the industry in the sense that they produce and distribute various unofficial recordings.

I will here focus on the most important arena for contemporary fandom, the Internet. There are fan pages devoted to presenting regular news on what happens in the world of Bob Dylan (Expecting Rain); listing every song from every concert or recording session (Björner); or presenting and reviewing bootleg records (Bobsboots). In addition, there are of course a number of discussion forums (e.g. Love and theft; My back pages). There are many arenas for fan distribution of audiovisual material; some larger sites, for example YouTube, hosting a great variety of material, including material on Dylan; others exclusively devoted to this artist (Rare Dylan Recordings).

There are also several web pages dedicated to issues on Dylan and religion. The blog Dylan Devotional calls itself a 'resource blog for spreading the gospel of Bob Dylan worship music'. A website called 'A Lily among thorns' is dedicated to 'exploring Bob Dylan's Christianity', and presents analyses of songs, interviews as well as transcripts of stage speeches from the gospel period concerts. The site called 'Not dark yet' analyses many of Dylan's songs, both old and new, tries to connect the lyrics to various biblical passages, and argues that Dylan has recently been singing more of these 'biblical' songs than in previous years. There is also a fan site devoted to a religious follow- 
ing of Dylan, including a religious calendar and a list of the saints of 'bobism' (Church of Bob). ${ }^{8}$

Religion also appears as a topic in online discussion forums on Bob Dylan. One recurring topic is the question regarding Dylan's current relationship to religion in general and Christianity in particular. I will here present some quotes from one such discussion thread on the discussion forum at the Expecting Rain website (Bob and religion). The discussion was conducted in September 2006 and contains 87 messages written by 24 different forum members.

The discussion starts with the question: 'I was just wondering if he is still a strong [C]hristian?' The answers to the question are both affirmative:

I think you['re] an idiot if you are in the camp that likes to believe th[at] Dylan has completely abandoned everything he stood for in the early eighties. There are just too many signs to prove otherwise. I do however think, that he quickly realized that when you are Bob Dylan, you can't keep up the christian public persona he had created and not get shot

and negative:

I think the particular strain of christianity he got involved with in the late 7os did represent a phase that he passed through. The Vineyard Church has all the criteria of a cult short of the tainted Kool-Aid. . . I doubt he [k]ept most of the born-againers he picked up during his 'Saved' period.

These quotes are examples of two different interpretations of Dylan's relationship to religion. One interpretation emphasises a continuing relationship, where religion, and perhaps even Christianity, has always been a part of Dylan's life; while the other interpretation sees the 'Christian period' as an exception and religion as more or less irrelevant during the rest of his career. In the critical literature, Marshall (2002) is a clear example of the former while Williams (1980) is more of an example of the latter.

8 Other examples of-what I understand as ironic-constructions of a religious following of Dylan include two books by a Norwegian author, Carl Johan Berg, on Dylan's 'disciples' and Dylan's 'gospel' (Rakvaag 2007; Berg 2007); as well as a feature in the music magazine Uncut, which asked its readers the rhetorical questions 'Is Bob Dylan a God?' and 'Should we worship Bob Dylan?' 
There are also examples from other online discussions of fans relating Dylan to other religious traditions than Christianity. One further quote from the above quoted discussion (Bob and religion) emphasized a continuing relationship to religion, but not to Christianity: 'I've heard him talk about eastern philosophies and yoga and meditation, he's obviously been around the block religion wise.'

On the same discussion forum, one fan started a discussion thread with the title 'Dylan Akbar', and after every mention of Dylan's name added 'may peace be upon him', thus tying Dylan to Islamic tradition and even implying that Dylan is a prophet of Allah (Dylan Akbar); and other fans have wondered about Dylan's possible relations to freemasonry (Is Bob Dylan a Mason in Distress?), or whether he perhaps has sold his soul to the devil (Did Dylan sell his soul to the Devil?).

\section{Concluding remarks}

This article has been a presentation of some examples of how a particular rock artist, Bob Dylan, is related to various religious traditions in different discourses around the artist and his works. This construction of Bob Dylan as a religious figure, as it were, is seen as an example of how religion relates to an important sphere in contemporary society: popular culture.

The discussion has revolved around the construction of Bob Dylan as a rock star and particularly ways in which his artistry relates to religion. Examples have been presented of how Dylan's own biography and works, but in particular media and fan response, relate to religion and create a connection between Dylan and religious traditions. I have first and foremost attempted to argue that religion is an important category in the constructions of the meaning of the rock star Bob Dylan. I hope that the examples also show that the interpretations are quite varied, where some-particularly Christian-interpreters emphasize Dylan's relationship to Christianity, but where the wider view shows a more ambivalent picture.

I see the connections made between Bob Dylan and various religious traditions as examples of sacralization. The discourses on Dylan and religion are to me an example of how religion is evoked in the contemporary public sphere. It is impossible on the basis of the material in this article, and difficult even in a more general discussion on religion and popular culture, to claim with any certainty that there is an increase of references to religion within contemporary popular culture, although this is sometimes argued (Possamai 
2005; Hoover 2006). But it is also difficult to completely ignore the fact that religion appears within popular culture in various forms, and that this is also acknowledged in fan and media discourses on popular culture. Furthermore, it is clear to me that these connections between religion and popular culture constitute interesting and important changes in the position of religion in contemporary society.

\section{Sources}

\section{Internet sources}

\section{First Gospel Tour}

http://www.bjorner.com/DSN05060\%201979\%2oFirst\%2oGospel\%2oTour.htm\# DSNo5270 (accessed on 29 October 2008).

\section{A Lily among thorns}

http://www.alilyamongthorns.8m.com/ (accessed on 29 October 2008).

\section{Björner}

http://www.bjorner.com/bob.htm (accessed on 8 October 2008).

\section{Bob and religion}

http://www.expectingrain.com/discussions.html (accessed on 14 September 2006).

\section{Bob Dylan official homepage}

http://www.bobdylan.com/ (accessed on 3 November 2008).

\section{Bobsboots}

http://www.bobsboots.com/ (accessed on 8 October 2008).

\section{Church of Bob}

http://www.geocities.com/churchofbob/ (accessed on 3 November 2008).

Did Dylan sell his soul to the Devil?

http://expectingrain.com/discussions.html (accessed on 14 February 2006).

\section{Dylan Akbar}

http://www.expectingrain.com/discussions.html (accessed on 30 October 2006).

\section{Dylan Devotional}

http://dylangospel.blogspot.com/ (accessed on 29 October 2008).

Dylan on ' 60 minutes'

http://www.youtube.com/watch?v=BS 5 MwoqDTSY\&feature=related (accessed on 29 September 2008).

Dylan - The Yearly Chronologies

http://www.bjorner.com/chronologies.htm (accessed on 26 September 2008).

Expecting Rain

http://www.expectingrain.com/ (accessed on 8 October 2008). 


\section{Gregory, Chris}

2007 From the Pen of Chris Gregory: Bob Dylan's Modern Times track by track. http://www.chrisgregory.org/blog/CategoryView,category,Bob\%2BDylan\% 27s\%2BModern\%2BTimes\%2BTrack\%2BBy\%2BTrack.aspx (accessed on 8 April 2009).

\section{Hurst, Josh}

2006 Bob Dylan: Modern Times [review]. Christianity Today. http://www.christianitytoday.com/music/glimpses/2006/moderntimes.html (accessed on 29 September 2008).

\section{Is Bob Dylan a Mason in Distress?}

http://expectingrain.com/discussions.html (accessed on 17 February 2006).

\section{Kultursamverkan}

http://www.kultursamverkan.se/arkiv/gudstjanster.htm (accessed on 29 October 2008).

\section{Love and theft}

http://loveandtheft.se/smf/ (accessed on 6 October 2008).

\section{Løvli, Geir}

2002 Dylan en messe verdt. Fredrikstad Blad 30.1.2002. http://www.fb.no/apps/ pbcs.dll/artikkel? Avis $=$ FB $\&$ Dato $=20020130 \&$ Kategori $=$ SPEILET $\&$ Lopenr $=$ $50058869 \&$ Ref $=$ AR (accessed on 29 October 2008).

\section{My back pages}

http://www.my-back-pages.com/forums/index.php?act=idx (accessed on 8 October 2008).

\section{Nicola Menicacci videos}

http://www.nicolamenicacci.com/bd/videos/english.htm (accessed on 29 October 2008).

\section{Not dark yet}

http://notdarkyet.tripod.com/ (accessed on 29 October 2008).

\section{Pareles, Jon}

2006 The Pilgrim's progress of Bob Dylan. New York Times 20.8.2006. http://www. nytimes.com/2006/08/20/arts/music/2opare.html (accessed on 29 September 2008).

\section{Rakvaag, Geir}

2007 Stor tropå Dylan. Dagsavisen 30.8.2007. http://www.dagsavisen.no/kultur/ musikk/article312886.ece (accessed on 1 November 2008).

\section{Rare Dylan Recordings}

http://www.expectingrain.com/discussions/viewforum.php? $\mathrm{f}=9 \&$ sid=a87162a228d 3 b9b777a965coodb32bec (accessed on 6 October 2008).

\section{Rennes-Le-Chateau: The Mystery}

http://www.renneslechateau.com/default-uk.htm (accessed on 29 October 2008).

\section{Saved 1980}

http://www.searchingforagem.com/1980s/Internationalo25.htm (accessed on 31 October 2008). 


\section{'Singer/Songwriter Bob Dylan Joins Yom Kippur Services in Atlanta'}

http://www.chabad.org/news/article_cdo/aid/573406/jewish/SingerSongwriter-

Bob-Dylan-Joins-Attends-Yom-Kippur-Services-in-Atlanta.htm (accessed on 29 October 2008).

\section{The Annotated Friend of the Devil}

http://arts.ucsc.edu/gdead/agdl/fotd.html (accessed on 8 April 2009).

\section{Theme Time Radio Hour}

http://www.bbc.co.uk/6music/shows/bob_dylan/ (accessed on 26 September 2008).

Uncut

http://www.uncut.co.uk/music/bob_dylan/special_features/8987 (accessed on 31 October 2008).

\section{Printed sources}

\section{Baigent, Michael, Richard Leigh \& Henry Lincoln}

2005 Holy Blood, Holy Grail: The secret history of Jesus, the shocking legacy of the Grail. New York: Bantam Dell. (First published in 1982)

\section{Berg, Carl Johan}

2007 Dylan's Disipler: Ikke helt som andre fans. Oslo: Koloritt.

\section{Bob Dylan 1975-1981}

2006 Bob Dylan 1975-1981: Rolling Thunder and the gospel years. Highway 61 Entertainment. (DVD)

\section{Bob Dylan 1978-1989}

2008 Bob Dylan 1978-1989: Both ends of the rainbow. Chrome Dreams. (DVD)

\section{Cartwright, Bert}

1985 The Bible in the Lyrics of Bob Dylan. Bury: Wanted Man.

Cott, Jonathan (ed.)

2006 Bob Dylan: The Essential Interviews. New York: Wenner Books.

Dylan, Bob

1980 Saved. Columbia. (CD)

Forbes, Bruce David \& Jeffrey H. Mahan (eds)

2000 Religion and Popular Culture in America. Berkeley: University of California Press.

\section{Friberg, Pär}

1999 Brustenhetens budbärare: En läsning av Bob Dylans sångtexter 1979-1997. Stockholm: Teologiska högskolan.

\section{Gilmour, Michael}

2004 Tangled Up in the Bible: Bob Dylan \& Scripture. New York: Continuum.

Gotta Serve Somebody

2003 Gotta Serve Somebody: The gospel songs of Bob Dylan. Columbia. (CD)

Gray, Michael

2000 Song \& Dance Man III: The art of Bob Dylan. New York: Continuum. 


\section{Häger, Andreas}

1996 Like a Prophet: On Christian Interpretations of a Madonna Video. In: Tore Ahlbäck (ed.), Dance, Music, Art and Religion; pp. 151-74. Åbo: The Donner Institute for Research in Religious and Cultural History.

2004 Religösa aspekter i verk och mediebevakningen av den svenska artisten Thomas Di Leva. Prismet: Religionspedagogisk tidskrift 55 (2): 57-65.

2005 Under the Shadow of the Almighty: Fan reception of some religious aspects in the work and career of the Irish popular musician Sinéad O'Connor. In: Michael Gilmour (ed.), Call me the Seeker: Listening to religion in popular music; pp. 215-25. New York: Continuum.

2006 Seek and you will find: A critical discussion of the search for "Christian" content in popular culture. In: Johanna Sumiala-Seppänen, Knut Lundby \& Raimo Salokangas (eds), Implications of the Sacred in (Post)Modern Media; pp. 217-33. Göteborg: Nordicom.

\section{Heylin, Clinton}

1990 Saved! Bob Dylan's conversion to Christianity. In: John Bauldie (ed.), Wanted Man! In search of Bob Dylan; pp. 128-34. New York: Citadel Underground.

2003 Bob Dylan: Behind the shades revisited. New York: HarperEntertainment.

\section{Hoover, Stewart M.}

2006 Religion in the Media Age. London: Routledge.

\section{Ledbury, John}

n.d. Mysteriously Saved: An astrological investigation into Bob Dylan's conversion into American fundamentalism. London: Quest Publications.

\section{Mäkelä, Janne}

2002 Images in the Works: a Cultural History of John Lennon's Rock Stardom. Turku: University of Turku.

\section{Marshall, Scott M.}

2002 Restless Pilgrim: The spiritual journey of Bob Dylan. Lake Mary: Relevant Books.

\section{Mazur, Eric Michael \& Kate McCarthy (eds)}

2001 God in the Details: American religion in popular culture. New York: Routledge.

Moaz, Daniel

2005 Shekhinah as woman: Kabbalistic references in Dylan's Infidels. In: Michael Gilmour (ed.), Call me the Seeker: Listening to religion in popular music; pp. 3-16. New York: Continuum.

\section{Pickering, Stephen}

1975 Bob Dylan Approximately: A portrait of the Jewish poet in search of God: A Midrash. New York: David MacKay.

\section{Possamai, Adam}

2005 Religion and Popular Culture. A Hyper-Real Testament. Brussels: Peter Lang. 
Ricks, Cristopher

2004 Dylan's Visions of Sin. New York: Ecco.

Saving Grace

2007 Saving Grace: The Gospel Songs of Bob Dylan. Zebra Art. (CD)

Shelton, Robert

1986 No Direction Home: The life and music of Bob Dylan. New York: Da Capo Press.

\section{Sounes, Howard}

2001 Down the Highway: The life of Bob Dylan. London: Black Swan.

Webb, Steven

2006 Dylan Redeemed: From Highway 61 to Saved. New York: Continuum.

Wenner, Jann S.

2007 Bob Dylan. Rolling Stone Magazine, May 3-17: 48-54.

Williams, Don

1985 Bob Dylan: The man, the music, the message. Old Tappan: Fleming H Revell. Williams, Paul

1980 What happened? Glen Ellen: Entwhistle.

2004 Bob Dylan: Performing artist 1974-1986. The middle years. Reading: Omnibus.

Woodhead, Linda \& Paul Heelas

2000 Religion in Modern Times: An interpretive anthology. Oxford: Blackwell. 